\title{
A reflective commentary about teaching international non- accounting postgraduates amid COVID-19
}

\begin{tabular}{|r|l|}
\hline Journal: & Pacific Accounting Review \\
\hline Manuscript ID & PAR-09-2020-0156.R3 \\
\hline Manuscript Type: & Research Paper \\
\hline Keywords: & $\begin{array}{l}\text { international students, accounting for non-accountants, COVID-19, } \\
\text { Emergency Remote Online Teaching (EROT), Accounting education, } \\
\text { Blended Teaching }\end{array}$ \\
\hline
\end{tabular}

SCHOLARONE $^{\mathrm{m}}$
Manuscripts 


\title{
Title: A reflective commentary about teaching international non- accounting postgraduates amid COVID-19
}

\begin{abstract}
Purpose: To highlight the experience of teaching accounting to non-accounting international postgraduates both pre and during COVID-19.
\end{abstract}

Design/methodology/approach: Reflections and anecdotal evidence from 550 students that experienced face-to-face and blended teaching mode in 2019 and 2020.

Findings: The accounting course is contextualised to non-accounting disciplines. International postgraduates showed varying levels of adaptability towards the blended teaching approach. During the lock-down, students from India were more vocal and sought assistance more than those from China. Chinese students asked for assistance only when it was necessary. Excessive emails from students seeking reassurances and affirmations were common during the lock-down, and therefore, there is a greater need for pastoral care.

Research limitations/implications: This paper evaluates the impact of COVID-19 on international students enrolled on one accounting course in one university in 2019 and 2020. The comments based on personal observations and experience may result in some subjectivity and bias.

Practical implications: The findings will help academics, institutional leaders and support staff to evaluate and improve teaching quality and service to international students.

Originality/value: With the uncertainty caused by COVID-19 and the commercialisation of global education, this study adds to the discussion of teaching accounting to nonaccountants during a crisis. It provides insights into the cultural influences and experiential differences relating to teaching international students. 
Keywords: International students, COVID-19, Accounting for non-accountants, blended teaching, Accounting education.

\section{Introduction}

Over the last four decades, global student mobility has significantly changed the student landscape and revenues for western tertiary education institutions (TEIs) worldwide. Incoming international students generated revenue not only through their education but also through accommodation, spending and tourism. For the past two decades, Asians constitute the highest number of international students entering western TEls (Bradley, 2008). Unfortunately, COVID-19 has threatened these revenue streams, with Australian TEls estimated to face a cumulative loss of $A \$ 10 b n$ to $A \$ 19 b n$ between 2020 and 2023 (Hurley \& Van Dyke, 2020, p. 3).

COVID-19 has caused unprecedented changes to TEls worldwide. TEls had to adopt emergency remote online teaching (EROT) and online assessments due to social distancing and campus closure. Academics were forced into new ways of working at short notice with little training and development time. They had to switch to EROT without fully comprehending the technological platforms for learning and assessment. This led to work intensification with rapid adaptation resulting in a significant shift in the balance between teaching and research (Krishnamurthy, 2020). EROT can be challenging for students, as some may not be prepared to learn at home independently. They faced technical difficulties, loneliness and a lack of self-motivation. These challenges are exacerbated significantly for those international students with language difficulties (Sonnemann \& Goss, 2020).

Some international students had experienced difficulty adapting to western TEls due to a lack of language proficiency (Lamberton \& Ashton-Hay, 2015), improper learning styles (Magnus, Polterovich, Danilov, \& Savvateev, 2002) and ignorance of the education system (Le \& McKay, 2018). Additionally, a cultural clash exists when collectivistic Asian students enter individualistic western TEls (Wong, 2004). 
The purpose of this reflective commentary is to highlight the experience of teaching an accounting course to non-accounting international postgraduates pre and during COVID-19. Even though the pandemic was unexpected and disruptive, it could be a blessing in disguise as TEls are forced to re-examine their teaching, research and support roles; and identify innovations. The pandemic has transformed how we teach and assess due to diminished relational interaction with the students and a greater reliance on technology. This study contributes to providing insights regarding the influence of culture when teaching and assessing international students; and extending the academic's role, including providing pastoral care and support role to students.

The paper is divided into several sections. The next section details the literature on international students and accounting for non-accountants. The third and fourth sections discuss the experience in teaching accounting to non-accounting majors pre and during COVID-19. Section five concludes.

\section{International students and Accounting for Non-Accounting Students}

\section{International Students}

International education is Australia's third and New Zealand's (NZ) fifth export earner generating more than $\mathrm{A} \$ 90 \mathrm{bn}$ (Calderon, 2020, p. 22) and NZ\$4.47bn (Universities New Zealand, 2018) to their respective economies. 27,690 international students were enrolled in NZ universities in 2018, and 40 per cent are in postgraduate programmes (Universities New Zealand, 2018). Chinese and Indian students are the two highest international student groups enrolled in NZ and Australian universities (Rafi \& Lewis, 2013). Some Australian universities derived more than 40 per cent of their international students' revenues (Birrell \& Betts, 2020). 
Prior research on international students have included social, cultural and academic aspects, including perceptions of prejudice, mental health and well-being (Brarnhardt \& Ginns, 2014); learning (Wearring, Le, Wilson, \& Arambewela, 2015); culture shock and cultural clash (Yang, Zhang, \& Sheldon, 2018); teaching and assessments (Edwards \& Ran, 2006); and language proficiency (Lamberton \& Ashton-Hay, 2015). Culture plays a big part in their learning and interaction with teachers and peers (Jones, 2005).

\section{Accounting for non-Accountants}

Non-accounting students have viewed accounting as a complex subject, and they are turned off by it (Saudagaran, 1996). Accounting is considered the most challenging and "high risk" with high failure rates (Lloyd \& Abbey, 2009, pp. 23-24). Non-accounting students are unlikely to take accounting had it not been compulsory for their degree (Lois, Tabouratzi, \& Makrygiannakis, 2017). There is also a significant difference in the background and learning styles of accounting and non-accounting majors (Tan \& Laswad, 2006). Consequently, it was suggested that non-accounting majors should have a broad general knowledge of accounting rather than the technical proficiency for preparing accounts (Zukowsky, 1961). The focus should be on using and understanding accounting information instead of preparing accounting reports (Tan \& Laswad, 2006). Successful delivery of an accounting course can change the interest levels of non-accountants (Etter, Burmesister, \& Elder, 2000), and teachers play a critical role (Lois et al., 2017). With that, academics must be cognisant of the importance of changing non-accounting majors' perceptions about accounting. They should explore active learning and innovative strategies to motivate non-accounting majors to excel in accounting (Lloyd \& Abbey, 2009). Hence, it is beneficial to reflect on teaching accounting to non-accounting postgraduates pre and during COVID-19.

\section{Accounting for the Professional Masters in Business Programmes}


This commentary is about teaching an accounting course to non-accounting Professional Masters in a New Zealand university. International students are an integral part of this university, with the Chinese and Indians constituting the two largest international student population in 2019, especially for the Professional Masters programmes. On average, 80 per cent were international students from 2017 to 2020.

\section{Accounting for non-accounting postgraduates}

This paper teaches postgraduates/managers to make informed decisions based on financial and non-financial information obtained from fundamental financial and management accounting tools. The aim is to teach managers to identify, analyse, and interpret financial and non-financial information to evaluate, plan and control its resources within an organisation. It adopts a broad-based, integrated approach to accounting and applying it for decision-making. The pedagogy focuses on encouraging life-long learning with significant exposure to globalisation and the realism of business. It emphasises the usefulness of accounting information within a business and the related skills needed to work effectively in a business context.

There is a deliberate shift from the instructional delivery method as the emphasis is on "learning to learn". Accounting is taught from a user's perspective, which is practical and relevant. It provides insights into the results of management decisions and how they impact the business's overall financial performance, financial position, and cash-flow position. It also encourages students to view accounting as a social and organisational mechanism embedded in the practice of other functional areas of a business. The more critical issue is applying accounting concepts and locating the relevant information. Students are required to consider both accounting and non-accounting aspects of a business for decision-making. The assessments' core is not based on memorising facts but on locating and applying the information needed for decision-making. 
Guided by the literature to effectively teach accounting to non-accountants, these strategies are adopted:

(1) Emphasises areas that are important to the students, i.e. why accounting matters to their various professions. The focus is on a broad understanding of accounting and integrating it with other non-accounting courses (Lois et al., 2017). Practical and real-life examples of financial and management accounting used in finance, marketing, management, and information systems are included.

(2) Discusses the importance of qualitative information for decision-making, e.g., ratio analysis, capital investment appraisals, and decisions on relevant costings and budgets. This requires the teaching team's conceptual understanding of accounting and the practicality of accounting for decision-making.

(3) Provides opportunities for students to experience concepts in real-world situations. The paper emphasises the relevance, usefulness, and importance of accounting information for decision-making, which helps students learn and better position them in their profession.

The teaching team's enthusiasm and passion for teaching made a tremendous difference in changing the students' perception of accounting (Hossain, Heagy, \& Mitra, 2008). The course is delivered in an active participation/active learning environment (Etter et al., 2000). Active participation helps to improve learning as students put in more effort to understand the learning environment.

\section{Teaching International students}

As most international students are new to the course and country, they need support beyond lecture materials. They require more contact and assistance for assessment preparation (Rafi \& Lewis, 2013). Some were ill-prepared for their study in NZ due to a general ignorance of the place, culture and education system (Le \& McKay, 2018). 
It is observed that most international students are passive recipients of lectures due to their lack of accounting knowledge. International students struggle with critical and conceptual thinking, and independent learning appears foreign to them (Thomas, 2013). Chinese students seldom ask questions in class, as it is considered rude to challenge and interrupt the teachers. This is due to their "Confucian heritage" (Hall \& Sung, 2009), as teachers are regarded as people in authority with a wealth of knowledge (Edwards \& Ran, 2006).

Some Chinese students had language difficulties which affected their learning, critical thinking and assessments (Le \& McKay, 2018). Arguments and confrontations clash with their culture of the "face" system. Therefore, they strive to work for harmonisation in groups. They refrained from challenging the teaching team or peers. Consequently, most Chinese students will remain silent in groups, decreasing their contribution to group assessments (Hall \& Sung, 2009). It was evident that culture does play a significant role in their learning and assessment performance. With this in mind, the teaching team applied practical skills and cultural competency when teaching international students (Le \& McKay, 2018). A reflective attitude and the ability to step outside our norms was needed to appreciate the cultural challenges faced by international students. For example, many Chinese students do not seek clarifications nor contribute to the class. Instead, they reserved their queries and questions outside class hours. On the other hand, Indian students are more vocal and contribute more to class discussions, primarily because they are more proficient in English.

\section{Teaching, Learning and Assessment during COVID-19}

\section{EROT factors}

COVID-19 has resulted in unexpected and sudden economic, social and teaching repercussions for TEls. It has necessitated the most extensive and quickest transformation of academic and assessment practice ever seen in modern times. Entire student bodies have been abruptly shifted from face-to-face to remote online learning. The abrupt migration to 
EROT disrupted learning and teaching to students and academics. Fundamentally, COVID-19 challenges our core teaching activity with EROT replacing an interactive, personalised, and predominantly face-to-face experience that symbolises campus life. The "caught by surprise" EROT mode created uncertainty and fear amongst students, resulting in a floodgate of emails seeking clarity with class materials and assessments, particularly from international students. These concerns were magnified because Accounting is not their specialisation, and they were forced to learn it digitally.

Teaching is a social profession that emphasises relational practices between academics and students. At this university, the academics adapted their teaching to EROT within four weeks. Intensive digital training and support were received to help formalise online teaching and assessment. Online teaching is impersonal, and it challenges the relational aspect of teaching by not allowing significant interaction with students. Human interaction is critical for delivering an exciting accounting course, and this is a barrier with EROT.

The teaching team experienced intensified workload by familiarising digital platforms, adapting pedagogies, managing and organising teaching content, and finding new ways to engage with students. Other challenges include difficulty overseeing students' progress, answering a floodgate of email queries, and blurring work and personal time. During this time, some international students were disoriented, anxious, lonely and wanted constant affirmation. They needed psychological and moral support as most of them are away from home for the first time, and they are stuck in a foreign country. Consequently, academics were forced to extend pastoral care beyond teaching. Finally, the change to online assessments at relatively short notice presented particular concerns, especially maintaining rigour and standards (Brammer \& Clark, 2020).

Pre-COVID assessments were based on quizzes, group assignment and invigilated final exams. The aim of quizzes is for students to be familiar with accounting concepts. The group assignment incorporates team-based learning, where students evaluate a real organisation and come up with creative and innovative recommendations. The final exam assesses their 
application of knowledge and to problem-solve business decisions. Some questions require a "correct" answer.

During COVID, the number of assessments was reduced to two. Invigilated final exam was replaced with a final online assessment with 24 hours duration. The change in the assessment structure mid-way added a significant amount of work for the teaching team. In addition to retaining rigour and standard of assessment, the final assessment was reconstructed to avoid the "one correct" answer typical of invigilated accounting exams. The reconstructed final assessment assessed critical thinking, conceptual thinking, application of knowledge where there is more than "one correct" answer. This includes evaluating two real-life annual reports, understand the market realities, and know what is going on in the business environment politically, economically, socially and financially.

\section{International and non-accounting students' factors}

Learning an accounting course via EROT has heightened the anxiety and apprehension towards this subject amongst non-accounting students. There were significantly fewer queries during synchronous online sessions compared to face-to-face teaching. Nonaccounting students had more difficulty grasping accounting concepts online. They were less motivated to attend online classes, and many felt disengaged with the subject due to the little or no personal interaction with the lecturer. A lack of students' subject preparation before classes was also noticeable. Chinese students no longer ask questions during synchronous sessions. Instead, they reserved their queries to emails. The majority needed more guidance and support for assessments, reinforcing the view from a cultural perspective that teachers are the centres of knowledge.

Student lives also changed in many ways with the separation from their campuses and the need for learning online using digital technology. The challenges students faced were time management, information overload, independent learning and alienation from peers. These 
were overwhelming and have led to significant stress and anxiety as they had to learn an unfamiliar subject within a digitalised environment. However, online lectures were preferred by some students as they can learn at their own pace. Summative students' evaluation regarding online teaching were mixed, as indicated by several excerpts below:

- It was going pretty well the first three weeks when we had face-to-face learning but went downhill once we moved online.

- The recordings could help me to look back at the content

- Online lectures were interesting and helpful

- I wanted to attend live classes rather than online classes

In summary, the comparisons between teaching, learning and assessments pre and during COVID-19 are shown in Table I.

Table I: Comparisons between teaching, learning and assessment pre and during COVID-19 Pre COVID-19 During COVID-19

\begin{tabular}{|c|c|c|c|}
\hline & $\begin{array}{l}\text { Level of non- } \\
\text { accounting } \\
\text { students' } \\
\text { interaction and } \\
\text { class attendance }\end{array}$ & $\begin{array}{l}\text { - Medium to High } \\
\text { (between } 50-90 \% \text { ) }\end{array}$ & $\begin{array}{l}\text { - Low (between 40- } \\
50 \% \text { ) }\end{array}$ \\
\hline & $\begin{array}{l}\text { Role(s) of the } \\
\text { lecturer }\end{array}$ & $\begin{array}{l}\text { - Specialist in the } \\
\text { subject }\end{array}$ & $\begin{array}{l}\text { - Specialist in the } \\
\text { subject and IT } \\
\text { platform for online } \\
\text { classes } \\
\text { - Pastoral care to deal } \\
\text { with students' } \\
\text { mental health, fear } \\
\text { towards the subject } \\
\text { and homesickness } \\
\text { for international } \\
\text { students }\end{array}$ \\
\hline & $\begin{array}{l}\text { Teaching mode and } \\
\text { learning }\end{array}$ & $\begin{array}{l}\text { Face-to-face } \\
\text { teaching is personal } \\
\text { and informal } \\
\text { - Can observe the } \\
\text { level of students' } \\
\text { understanding } \\
\text { - Interactive and } \\
\text { collaborative - more } \\
\text { student-centred }\end{array}$ & $\begin{array}{l}\text { - Online teaching is } \\
\text { impersonal, formal } \\
\text { and less interactive } \\
\text { Difficulty in } \\
\text { observing the level } \\
\text { of students' } \\
\text { understanding } \\
\text { - Instructive - more } \\
\text { teacher-centred } \\
\text { recorded sessions }\end{array}$ \\
\hline
\end{tabular}




\begin{tabular}{|c|c|c|c|}
\hline & $\begin{array}{l}\text { Class preparation } \\
\text { by the teaching } \\
\text { team }\end{array}$ & $\begin{array}{l}\text { Strategies for } \\
\text { effective teaching } \\
\text { accounting to non- } \\
\text { accountants }\end{array}$ & $\begin{array}{l}\text { - Strategies for } \\
\text { effective teaching } \\
\text { accounting to non- } \\
\text { accountants } \\
\text { Digital literacy and } \\
\text { proficiency in online } \\
\text { delivery and } \\
\text { assessment } \\
\text { - Strategies for } \\
\text { organising and } \\
\text { managing contents } \\
\text { online for effective } \\
\text { engagement }\end{array}$ \\
\hline & $\begin{array}{l}\text { Monitoring non- } \\
\text { accounting } \\
\text { students' progress }\end{array}$ & $\begin{array}{l}\text { - } \\
\text { - Students are } \\
\text { continually querying } \\
\text { lecture materials } \\
\text { and assessments in } \\
\text { class }\end{array}$ & $\begin{array}{l}\text { - Difficult } \\
\text { - Students tend to } \\
\text { leave their queries } \\
\text { until just before } \\
\text { assessments are due }\end{array}$ \\
\hline & $\begin{array}{l}\text { Level of non- } \\
\text { accounting } \\
\text { students' } \\
\text { preparation for } \\
\text { classes }\end{array}$ & $\begin{array}{l}\text { Low }(15-20 \% \text { of the } \\
\text { students undertake } \\
\text { prior reading) }\end{array}$ & $\begin{array}{l}\text { Low to none }(0-10 \% \\
\text { of the students } \\
\text { undertake prior } \\
\text { reading) }\end{array}$ \\
\hline 7. & Assessments & $\begin{array}{l}\text { - } \text { Quizzes } \\
\text { - Group assignment } \\
\text { - Three hours } \\
\text { invigilated final } \\
\text { exams }\end{array}$ & $\begin{array}{l}\text { - Group assignment } \\
\text { - } 24 \text { hours non- } \\
\text { invigilated online } \\
\text { final assessment }\end{array}$ \\
\hline 8. & $\begin{array}{l}\text { Non-accounting } \\
\text { students' } \\
\text { perception of face- } \\
\text { to-face and online } \\
\text { classes }\end{array}$ & $\begin{array}{l}\text { Face-to-face } \\
\text { teaching is personal } \\
\text { and interactive } \\
\text { - Fixed class times and } \\
\text { self-discipline is } \\
\text { needed to attend } \\
\text { classes }\end{array}$ & $\begin{array}{l}\text { - Online sessions are } \\
\text { less personal and } \\
\text { interactive. } \\
\text { - More flexibility as } \\
\text { classes are recorded }\end{array}$ \\
\hline 9. & $\begin{array}{l}\text { Level of non- } \\
\text { accounting } \\
\text { students' } \\
\text { apprehension } \\
\text { towards Accounting }\end{array}$ & - Medium to high & - High to very high \\
\hline & $\begin{array}{l}\text { International } \\
\text { students' } \\
\text { perceptions }\end{array}$ & $\begin{array}{l}\text { - Felt like being part of } \\
\text { a student body on } \\
\text { campus. Can meet } \\
\text { with fellow students } \\
\text { and lecturers face- } \\
\text { to-face }\end{array}$ & $\begin{array}{l}\text { The virtual meeting } \\
\text { does not feel like } \\
\text { part of being on } \\
\text { campus. Cannot } \\
\text { meet with students }\end{array}$ \\
\hline
\end{tabular}




\begin{tabular}{|c|c|c|}
\hline & $\begin{array}{l}\text { - Having only to } \\
\text { understand the } \\
\text { subject and do well } \\
\text { in the paper }\end{array}$ & $\begin{array}{l}\text { and lecturers face- } \\
\text { to-face } \\
\text { Very apprehensive } \\
\text { as Accounting is } \\
\text { perceived as } \\
\text { complicated and } \\
\text { having to deal with } \\
\text { an online learning } \\
\text { platform }\end{array}$ \\
\hline $\begin{array}{l}\text { 11. Platforms used by } \\
\text { non-accounting and } \\
\text { international } \\
\text { students for queries }\end{array}$ & $\begin{array}{l}\text { Some queries were } \\
\text { asked during class } \\
\text { and outside class } \\
\text { times (e.g. after class } \\
\text { or during office } \\
\text { hours) } \\
\text { - Some email queries }\end{array}$ & $\begin{array}{l}\text { - A few queries, } \\
\text { mainly from } \\
\text { domestic students } \\
\text { during synchronous } \\
\text { sessions } \\
\text { Extensive email } \\
\text { queries from } \\
\text { international } \\
\text { students }\end{array}$ \\
\hline $\begin{array}{l}\text { 12. Collaborative } \\
\text { learning for non- } \\
\text { accounting and } \\
\text { international } \\
\text { students }\end{array}$ & $\begin{array}{l}\text { - Collaborate in } \\
\text { person and online } \\
\text { for group } \\
\text { assignment and } \\
\text { lectures }\end{array}$ & $\begin{array}{l}\text { - Collaborate online. } \\
\text { International } \\
\text { students with } \\
\text { language difficulty } \\
\text { found this } \\
\text { challenging }\end{array}$ \\
\hline
\end{tabular}

\section{Conclusion}

COVID-19 has placed a spotlight on education in TEls worldwide by the rapid changes to the nature of work, coupled with increased job insecurity and caring responsibilities for students. Whilst this may be a daunting prospect, it requires academics to be resilient. The implications are that academics need to evolve from traditional and familiar teaching methods to address changes, crises, and government regulations during these unprecedented times. These uncertain times require us to be flexible, agile, nimble and adaptable. Traditional contents may need modifications to incorporate this pandemic's effects, e.g. staff redevelopment, redeployment or multitasking, and lean management practices. 
This pandemic can be a blessing in disguise with new opportunities to explore, such as effective accounting teaching. First, we need to redesign and improve our accounting courses and online delivery to make them relevant and understandable to non-accountants. The accounting course needs to be future proofed with the agility and adaptability that can respond effectively in a crisis. This requires us to embrace changes, including digital teaching, and consider using various teaching aids to engage non-accountants. Those who proactively embrace digital teaching can derive a sustainable competitive advantage as the education sector transitions more to digitalisation. For example, COVID-19 has motivated the teaching team to use various visual and non-visual aids to simplify accounting concepts for non-accountants. Storytelling and current "breaking news" regarding real business organisations have garnered students' interest in accounting. To meet the onshore and offshore students' demands, we have both real-time virtual and in-class lectures. Academics are also mindful of the underlying cultural issues when teaching international students. The impact of COVID also forced academics to extend pastoral care in addition to teaching. Satisfactory students' evaluations indicate some success with these teaching modes though there is room for improvement. Second, we need to respond accordingly and speedily to any changes and challenges. As for this university, the continual research on international and non-accounting students and digital platforms have shaped the teaching delivery and assessments. The resultant effect is replacing invigilated exam with the final online assessment that non-accounting students favoured. We emphasised accounting dynamics to reflect managements' decision towards changes in the business environment (such as caused by COVID) which forms the core for teaching accounting to non-accountants.

Additionally, COVID-19 opens new research opportunities about its impact on international students. This includes teaching and learning pedagogies; experiential differences of nonaccounting majors by undergraduates and postgraduates towards accounting; practical assessments of the blended teaching model; engaging with culturally diverse student groups online and face-to-face; professional development requirements for academics with the blended approach; and finally, new research frontiers for academics. These research frontiers include identifying the changing, new and extended roles of academics, revising 
teaching materials to incorporate the effects of COVID-19 on businesses and exploring new ways to retain or enhance students' interest in Accounting.

This reflective commentary is limited by the academic's experience in teaching one accounting course within one university. The author acknowledges the partiality and anecdotal evidence used. International students are not homogenous; therefore, the observations capture only specific characteristics and patterns. One may overlook individual differences, motivations and personalities.

Finally, as accounting academics, we need to respond, recover and reimagine (Maritz, 2020) from the pandemic. We need to respond and address immediate operational continuity of teaching and research. We need to recover by recalibrating where possible the teaching and learning using EROT. Finally, we need to explore new teaching and research opportunities that shape the next "new normal". By doing so, it ensures that accounting academics can be resilient and triumph over this crisis. 


\section{References}

Birrell, B., \& Betts, K. (2020). The Crisis in the Overseas Student Industry: How Should Government Respond? Research Report June 2020. Retrieved from

Bradley, D. (2008). Review of Australian Higher Education: Final Report, December 2008. Retrieved from Canberra:

Brammer, S., \& Clark, T. (2020). COVID-19 and management education: Reflections on challenges, opportunities, and potential futures. British Journal of Management, 31, 453-456.

Brarnhardt, B., \& Ginns, P. (2014). An alienation-based framework for student experience in higher education: new interpretations of past observations in student learning theory. Higher Education, 68(6), 789-805.

Calderon, A. (2020). What will follow the international student boom? Australian Universities' Review, 62(1), 18-25.

Edwards, V., \& Ran, A. (2006). Meeting the Needs of Chinese Students in British Higher Education. Reading, MA: University of Reading.

Etter, E., Burmesister, S., \& Elder, R. (2000). Improving student performance and retention via supplemental instruction. Journal of Accounting Education, 18(4), 355-368.

Hall, G., \& Sung, T. (2009). Mind the gap? A case-study of the differing perceptions of international students and their lecturers on postgraduate business programmes. International Journal of Management Education, 8(1), 53-62.

Hossain, M., Heagy, C., \& Mitra, S. (2008). Perceptions of non-accounting business majors about the Managerial Accounting course. Review of Pacific Basin Financial Markets and Policies, 11(4), 569-590.

Hurley, P., \& Van Dyke, N. (2020). Australian Investment in Education: Higher Education. Retrieved from Melbourne:

Jones, A. (2005). Culture and context: Critical thinking and student learning in introductory macroeconomics. Studies in Higher Education, 30(3), 339-354.

Krishnamurthy, K. (2020). The future of business education: A commentary in the shadow of the COVID-19 pandemic. Journal of Business Research, 117, 1-5.

Lamberton, G., \& Ashton-Hay, S. (2015). Preparing Chinese international business students for the transition to undergraduate study in Australia. Journal of Research in International Education, 14(2), 155-171.

Le, H., \& McKay, J. (2018). Chinese and Vietnamese international students in Australia. International Journal of Education Management, 32(7), 1278-1292.

Lloyd, C., \& Abbey, A. (2009). Teaching elementary accounting to non-Accounting majors. American Journal of Business Education, 2(2), 23-30.

Lois, P., Tabouratzi, E., \& Makrygiannakis, G. (2017). Accounting Information Systems course: perceptions of accounting and non-accounting students. EuroMed Journal of Business, 12(3), 258-268.

Magnus, R., Polterovich, V., Danilov, D., \& Savvateev, A. (2002). Tolerance of cheating: An analysis across countries. The Journal of Economic Education, 33(2), 125-135.

Maritz, A. (2020). A multi-disciplinary business approach to COVID-19: La Trobe Business School perspectives. International Journal of Organizational Innovation, 13(1), 45-62.

Rafi, B., \& Lewis, P. (2013). Indian higher education students in Australia: Their patterns and motivations. Australian Journal of Education, 57(2), 157-173.

Saudagaran, S. (1996). The first course in accounting: an innovative approach. Issues in Accounting Education, 11, 83-94.

Sonnemann, J., \& Goss, P. (2020). COVID Catch-Up: Helping Disadvantaged Students Close the Equity Gap. Retrieved from Victoria: 
Tan, L., \& Laswad, F. (2006). Students' beliefs, attitudes and intentions to major in accounting. Accounting Education: An International Journal, 15(2), 167-187.

Thomas, L. (2013). Internationalisation of the undergraduate business programs: Integrating international students. Business Education Innovation Journal 5(1), 74-82.

Universities New Zealand. (2018). New Zealand's Universities: Key Facts \& Stats, September 2018. Retrieved from https://www.universitiesnz.ac.nz/

Wearring, A., Le, H., Wilson, R., \& Arambewela, A. (2015). The international student experience: an exploratory study with students from Vietnam. The International Education Journal: Comparative Perspectives, 14(1), 71-89.

Wong, J. (2004). Are the learning styles of Asian international students culturally or contextually based? International Education Journal, 4(4), 154-166.

Yang, Y., Zhang, Y., \& Sheldon, K. (2018). Self-determined motivation for studying abroad predicts lower culture shock and greater well-being among international students: the mediating role of basic psychological needs satisfaction. International Journal of Intercultural Relations, 63, 95-104.

Zukowsky, W. (1961). Essential subject matter for a one-year basic accounting course offered to nonaccounting majors. The Accounting Review, 36, 481-487. 